Ayurlog: National Journal of Research in Ayurved Science

Website: http://www.ayurlog.com $\quad$ Volume: $6^{\text {th }} \mid$ Issue: $7^{\text {th }} \mid$ Oct- Dec 2018

\title{
A Review study of Kriya sharir of Kesh (Hairs)
}

\section{Chandrasekhar Y Bangarwar*1, Sanita A Eppalpalli ${ }^{2}$}

1. Prof. \& Head Dept. of Kriya Sharir, Glocal College of Ayurvedic Medical Science \& Research Centre, Behat Dist. Saharanpur ( Uttar Pradesh).

2. Assistant Professor, Dept. of Kriya Sharir, Shree Narsingh K. Dube Charitable Trust's Ayurved Mahavidyalaya, Nallasopara, Dist. Thane, Maharashtra, India. Contact +91 9664268841. Email ID: drsanita29@gmail.com

*Corresponding author: bangarwar.aakash@gmail.com

\section{Abstract:}

Health comprises of both, body and mind. Ayurveda aims at maintaining the health of a healthy person and to treat the diseased. Scalp hair is responsible for beauty, appearance of personality and protection. "The hair is the richest ornament of a woman"- Martin Luther. It brings one's self-image into focus. There are an increasing number of panicked people coming to the doctor with the complaint of hair loss. Due to modern lifestyle, food, environment etc, people are more likely to lose hair at early age. Therefore more awareness about hair health is observed in the society. This article mentions the possible ways of enhancement of strength and beauty of scalp hair through the principles of achieving good health (Swasthy Prapti) as explained in Ayurveda. The scope of this article deals with understanding of all aspects of Kesha (Hair) mentioned in the Samhitas of Ayurveda.

Key words: Kesh, Kesha Swasthya, Beauty,

\section{Introduction}

Ayurveda is an ancient and developed science of India. Kesha (hair) is a complex and delicate part of our body, which gives a personality. Beautification is the process of making visual improvements to a person, place or thing. The concept of beauty in Ayurveda is not only in achieving an attractive external appearance but also gaining good health longevity.

Most of the practices in maintaining good health mentioned in Ayurveda are dependent on seasonal variations (Ritus) and are found subtly interwoven with daily routine practices (Dinacharya).

Today in this era, human health is detoriating day by day; this also counts health of hair. Globalization being major factor, stress, unhealthy food habits, is also responsible for damaging and making hair unhealthy. Any time an individual has any kind of health concern from stress, trauma, medications of various sorts, chronic medical conditions or medical conditions that come and then wane, heavy metals in waters and food, smoking etc. these and more can affect the hair, its growth, and its appearance.

To overcome these hair related problems, various hair cosmetics and hair 
care therapies have emerged. But these cosmetics and therapies have their own drawbacks. So, Ayurveda, at this stage is found to be more promising and result oriented with absolute no drawbacks.

In Ayurveda, scattered references are available on maintaining the health and longevity of hair. It has explained few concepts for achieving good health. This article tried to explain these concepts with respect to beauty of hair. For this reason, a literary study has been made, to collect all the references at one place. This study gives details of the various concepts mentioned in Ayurveda such as Dinacharya, Ritucharya, Sadavritta, etc. related to Kesha Swasthya and therapies like Nasya, Shiro Abhyga, Shiro Lepan, Kesha Rasayanas etc.

\section{REVIEW OF LITERATURE}

According to Drug and Cosmetic Act (India) 1940, cosmetics are defined as any substance rubbed, poured, sprinkled or in any way applied to human body for cleansing, beautifying, and promoting attractiveness $^{1}$. Ayurvediya concept of beauty and cosmetics started from the inheritance and pursuance of ideal life style i.e, Dinacharya, Ratricharya, Ritucharya, Sadavrutta etc.

The healthy hairs should be soft, black in colour, small, firm, oily and with a single hair root. These qualities of healthy hairs are criteria to determine the "Dirghayu" of a person $^{2}$.

Twak is a Adhisthan of Kesha. Some part of Kesha lies above the Twak which is known as Kaanda. The tip of Kaanda is known as Romaagra. The enlarged part in the twak is called as Mulabhaga, The Sira,
Dhamanî, Snayu are connected to this region. This part is known as Romakupa. Sweating expelled out from this region and the nutrition is supplied by Rasavahin $\hat{\imath}^{3}$.

Relation between Kesha and Dosha, Dhatu, Mala

\section{Kesha and Tridosha}

There is a very close functional relation between Kesha and Tridosha. The health of Kesha is depends on Dosha when they are in equilibrium state. Kapha Dosha provides Brumhan and Pitta Dosha softness to the hairs however these two Dosha are depend on functions of Vata Dosha. The Romakupa are a site of sensation and are supplied by a number of capillaries. The sensation is carried by Prana Vayu and Romaharsha is exhibited by the Vyana Vayu. ${ }^{4}$

\section{Kesha and Sapta Dhatu}

The skin receives nourishment from Rasa hatu. Kesha is a part of Twak. Therefore Kesha also receives nutrients from the Rasa Dhatu. Premature graying of hair is caused by the vitiation of Rasa Dhatu. Individuals having Twak Saarata are characterized by unctuous, smooth, soft, clear, fine, less numerous, deep rooted and tender hair and lustrous skin. A person possesses Meda Sara exhibits Snigdha Nakha, Kesha, Loma etc ${ }^{5}$ as it gets Snigadhata from Meda Dhatu.

\section{Kesha and Mala}

Kesha is the Mala of Asthi dhatu ${ }^{7}$ and Upadhatu of Majja ${ }^{8}$ consequently whenever there is a Vrudhi and Kshaya of Asthi Dhatu ${ }^{9}$ there it will affect the growth and development of the hairs. This is observed through the sign and symptoms of the Asthi Kshaya i.e. falling of hair, nails, hair of the beard, including mustaches and teeth, excreation and 
loosness of joints ${ }^{10}$. There is close relation between Kesha and Shukra Dhatu. Appearance of mustache and beard is the sign of developed Shukra Dhatu. In female also Yoniromata and Kesharajita are the signs of developed Shukra Dhatu. According to Dhalhana Acharya after the complete development of Shukra Dhatu there is appearance of its Mala i.e. Smashru ${ }^{11}$.

\section{Kesha and Strotas}

The sites of origin of the Srotas carrying sweat are Medomula and Romakupa. The characteristic manifestations of their vitiation are the absence of perspiration, excessive perspiration (sweating), roughness of body, general burning sensation and horripilation (Romharsha) ${ }^{12}$.

Concept of health and beauty in Ayurveda

The concept of health and beauty includes four aspects as explained in Ayurveda.

Dinacharya, Rirucharya and Sadvrutta

These aspects should be properly followed to maintain good health.

A) Dinacharya ${ }^{13,14}$

1. Healthy person should always wake up early during 'Brahma Moohurta' in the morning, i.e, at around $4 \mathrm{am}$. This habit always safe guards the life of that person. As per routine, one should let the body do its defecation process.

"Brahmhe Moohurte Uttishteta Swasthyo Rakshartham Ayushyah \|

Sharira Chintaam Nirvatya Kruta Shoucha Vidhistatha ||"As. Hr. So. 2/1

2. Snanam-Bathing is the process which removes dirt, itching, tiredness, sweat, lithargy, thirst, heat, and sins from the whole body and mind. It improves digestive fire, strength, luster and virility. Acharya Charaka described it to be Ojaskar i.e, healthy.

"Deepanam Vrushyam Aayushyam Snanam Oorja Bala Pradam |

Kandu Mala Shrama Sweda Tandra Truda Daha Papma Jita \|" As. Hr. So. 2/15

\section{"Snanam Ojaskaram Param ||"} Ch. So. $5 / 94$

One should never do head bath with warm water. It harms the strength and health of hair as well as eye sight. Instead cold water head bath will protect the harmful effects on hair and eye sight.

"Ushnambu Na Adha Kayasya Parisheko Balaavah |

Tenaiva Cha Uttamangasya Bala Hruta Kesha Chakshusaam ||” As. Hr. So. 2/16

3. Kshoura Karma- Regular cutting of excess growth of nails, hair, beard and moustache is said to be followed in Dinacharya. Bathe daily as routine.

"Neecha Roma Nakha Smashru Nirmalanga Ghrimalayana

Snanasheelam....||"

As. Hr. So. $2 / 30$

Practicing (regular following) shaving, cutting and grooming of hair and nails regularly is described to be providing health, virility, longevity, spirituality and beauty to the person.

"Poushtikam Vrushyam Aayushyam Shuchi Roopa Virajanam 
Kesha Smashru Nakhaadinaam Kalpanam Samprasadhanam |" Ch. So. 5/99

4. Dhoomapana - Smoking (with medicinal drugs) done as per classical methods (inhaling and exhaling smoke through mouth) will always protect the health of hair and prevents alopecia (Khalitya), premature greying of hair (Pinjaratva) and hair fall (Kesha Patanam).

"Khalityam Pinjaratvam Cha Keshaanam Patanam Tatha....

Dhoomavaktrakapaanasya

Vyadhayah Syuh Shirogataah \| Ch. So. 5/30, 33

5. Nasya- Every person should do Nasya Karma (A procedure of putting nasal drops in the nostrils- Nostrils are considered as a direct route to enter the brain in Ayurveda) with Anu Tail each year during Pravruta, Sharad, Vasanta Ritu when the sky is not covered with clouds. This procedure prevents greying and browning of hair (over scalp as well as body). It prevents hair fall and also strengthens the hair roots for healthy hair growth.

"Varshe Anu Tailam Cha Kaleshu

Trishu Na Chareta \|

Pravruta Sharata Vasanteshu

Gatameghe Nabhastale |....

$\mathrm{Na}$ Syuh Shweta Na Kapilah Keshah Smashruni Va Punah \|

$\mathrm{Na}$ Cha Keshah Pramuchyante Vardhante Cha Visheshatah|" Ch. So. $5 / 56-58$

6. Shiroabhyanga- Daily oleating the scalp hair will prevent from headache, alopecia; premature hair greying and hair fall. This practice strengthens the scalp, hair follicle roots and ultimately makes hair grow really long and extra dark. Shiroabhyanga enlightens the sensory receptors, makes the skin shine and glow. It also gives a peaceful sound sleep in the night.

"Nityam Snehardra Shirasah Shirashoolam Na Jayate \|

$\mathrm{Na}$ Khalityam $\mathrm{Na}$ palityam $\mathrm{Na}$ Keshah Prapatanti Cha II

Balam Shira Kapalanaam Visheshenabhi Vardhate ...Ch. So. 5/81-84

\section{B) Ritucharya}

Seasonal changes also bring causation of many diseases. Abhyang, Utsadana, Pradeha Pralepa etc have been quoted in accordance with the respective Ritucharya as explained in the Samhitas. There is no direct reference to pathology of hair with respect to Ritu, but in general, health detoriates in these seasons if we do not follow the basic regime as advised. So by Yukti Pramana, Ritucharya should be followed to maintain good health of the body as well as hair.

1. Hemant Ritu- in this season there is aggravation of Sheeta (cold) quality of Vata Dosha, which makes the digestive fire extremely powerful. If appropriate quantity of food is not supplied, then the powerful digestive fire destroys the Rasa Dhatu in the body. Thus it ultimately aggravates Vata Dosha ${ }^{15}$.

As we know that Rasa Saara Purusha has good quality of skin and hair. If Rasa Dhatu gets destroyed then it affects the quality of skin and hair as well. 
So this Ritucharya should be followed to maintain the health of body as well as hair. In this season, Abhyang (body oliation), Utsadana (application of unctuous body masks), Murdhani Taila Dharan (application of hair oil) etc is advised ${ }^{15}$.

2. Shishira Ritu- there is no much difference in Hemant and Shishir Ritu. It is adviced to stay in warm houses i.e, house having lesser room temperature. This prevents excess aggravation of Vata Dosha in the body ${ }^{15}$.

Vata Dosha and Asthi Dhatu have inverse relation with each other as explained in 'Ashrayashrayee Sambandh $^{16}$ of Dosha Dhatu and Mala'. Also Asthi Dhatu Mala is Kesha. So to maintain the health of Kesha, it is necessary to keep homeostatic balance between Vata Dosha and Asthi Dhatu.

3. Vasant Ritu- In this sseason the aggravated Kapha Dosha starts melting and impairs the digestive fire and thus creates a lot of body ailments. Hence in this season it is advised not to consume heavy (Guru), sour (Amla), sweet (Madhur), and oily (Snigdha) food. Also, the afternoon short snaps of sleep (Diwaswaap) post lunch is contraindicated $^{15}$.

This season is said to be ideal for treating diseases of Kapha Dosha by Vamana Karma. Khalitya, Palitya, Kesha Prapatan etc can be treated by this procedure.

4. Grishma Ritu- in this season, due to scorching, heat the body turns week, perspiration is excessive, which leads to fluid loss and impaired digestion. Pungent (Katu), sour (Amla) and salty
(Lavan) food consumption is contraindicated in this season ${ }^{15}$.

Kshara and Lavan Rasa consumption in excess quantity is one of the causes of Khalitya (Alopecia) as explained in Charak Samhita ${ }^{17}$.

5. Varsha Ritu- in this season due to rains the digestive fire becomes more impaired and leads to many diseases. Honey is advised to be the best in this season. Honey is Tridoshahara. It cures all the three Doshas and maintains good health ${ }^{15}$.

6. Sharad Ritu- in this season the body gets aggravated with Pitta Dosha. Virechana Karma is said ideal for the cleansing of Pitta Dosha from the body in this season. Rakta Mokshan is also considered best in this season which eliminates impurities (Dosha) which are accumulated in the blood ${ }^{15}$.

C) Sadavrutta ${ }^{18}$

It is the practice of Good Conducts. Practicing and nurturing good conduct has two benefits- good health (Aarogya Laabh) and control over senses (Indriya Vijay).

- Praise the God, Cow, Gurus, Brahman, Siddha Purush, and Teachers

- Worship the Agni (lord of Fire).

- Bathing in the morning and evening daily.

- Cleanse external openings (eyes, ears nose, mouth, rectum and urinary orifice) regularly. 
- Cut down the excess growth of nails, hair, beard, moustache twice a month.

- Always wear clean, washed and untorned clothes daily.

Apart from the above basic principles of healthy habits, few therapies are mentioned in Ayurveda for healthy hair.

\section{Therapies}

\section{Nityam Snehardra Shirasam ${ }^{19}$ - Daily oiling of hair}

Benefits of daily oiling of hair are

1. headache doesn't occur,

2. no falling of hairs,

3. no graying of hairs,

4. the roots of hairs are strengthen, they grow long,

5. Hairs grow black in colors and with good health.

\section{Nasya Karma $^{20-}$ Nasal drops}

\section{Benefits of Nasya Karma}

The hair doesn't grey, and also doesn't fall. The hair growth is proper with extralong and black in color. Nasya Karma not only has the impact on Scalp hair (Shirastha Kesha) but also on the beard and moustache.

3. Rasayanas for hair - Immunemodulatory medicine for health of hair.

- Brahma Rasayana ${ }^{21}$ is said to be 'Palitaamaya Varjitah'.

Brahma Rasayana effect on hairs states that graying of hair never ever occurs. So to maintain the beauty of black long healthy hair, Brahma Rasayana can be the best medicine.

- Narasimha Ghruta ${ }^{22}$ 'Keshair Bhangaanga Neelai'

Narsimha Ghruta is good for maintaining colour of hairs as black as a Bee (Bhunga -which wonders around flowers). That is it prevents graying of hairs and maintains the normal colour of hair i.e. blackish.

- Churnam Shwadanshtra Amalaka Amrutanam - Lihyaan Sa Sarpir Madhu Bhaga Mishram.....Samaah Shatam Jeevati Krushna Keshah \|

Powder of Shwadanshtra, Amalaki, Amruta with Ghruta and Madhu if taken as Rasayana, it prevents graying of hairs and maintains its health until 100 years of age ${ }^{23}$.

\section{Hair applications}

- Formula for regrowth of hair'Loma Sanjanana Yoga,24

Ash made out any of these body parts (Skin, body hair, horn, and bone) of a four legged animal, is mixed with oil.

Applied- This formulation can be applied to see its result on scalp where hair growth is obliterated due to scar formation.

- Removal of unwanted hair'Loma Shatan Upaya,25 
Various applications are mentioned in Sushruta Samhita for the removal of unwanted hairs on body

$>$ Shanka bhasma + Hartal Bhasma in the ratio 2:1, mix with Kanji.

$>$ Bhallatak Oil + Snuhi Ksheer.

> Shyonak Bhasma + Hartal Bhasma + Shami Beej + Kadali + Lavan, mix with water.

Tail of domestic lizard + Kadali + Hartal Bhasma + Ingudi Beej Bhasma, mix with oil and water and dry under sunlight.

Applied - These hair applications can be made use in removal of unwanted hair growth over chin in females with PCOS.

- To maintain hair forever black a formulation from the book Chikitsaprabhakar

(Streerog Prakaran)

Mix Triphala and Loha Bhasma with water, add equal quantity of coconut oil, add 1/4 water and heat, then add Bhringraj Swaras, than store within an air tight bottle to keep it underground for one month. Apply this oil on scalp hair, than the head should be covered with leaves of banana overnight. Next day hair is washed with Triphala Decoction.

\section{DISCUSSIONS}

1. The features of hairs are different in various Saara Prakruti. Twak Saara Purush is characterized by unctuous, smooth, soft, clear, fine, less numerous, deep rooted, tender hair and lustrous skin and Meda Sara exhibits Snigdha Nakha, Kesha, Loma etc as it gets Snigadhata from Meda Dhatu.

2. The practice of Abhyanga as mentioned in Dinacharya seems to be useful in maintaining health of hair.

3. 'Murdhni Taila Dharan' i.e. application of oil on the scalp is advised in Hemanta Ritu by Charaka Acharya.

4. Practicing these daily and seasonal regimes (Shiroabhyang, Kshour Karma, Nasya Karma etc) will help in maintaining good health of body as well as hairs.

5. Various Rasayana medicines are mentioned in these classical texts for the good health of hair.

\section{CONCLUSION}

Hair is one of the most ornamental parts in a human body. It gives a personality to a person. The Kesha, Bala, Varna etc features are inherited by virtue of one's Prakriti i.e. the features bestowed to human at athe time of birth. This inherited Prakriti cannot be changed. Hence all the therapeutic efforts in Ayurveda are aimed at keeping the features under normal physiological conditions i.e. Prakrit Avastha. "We are what we eat" but it's better to say "We are what we digest". So beautification begins with proper nutrition, 
efficient digestion and assimilation of nutrients by the body and regular elimination. Therefore the concept of beauty in Ayurveda doesn't only consider the external appearance of a person, but also includes life style and therapeutic procedures for the promotion of one's overall health thereby granting beauty to the body.

\section{REFERENCES:}

1. Hazra J, Panda AK 2013 Concept of Beauty and Ayurveda Medicine. J Clin Exp Dermatol Res 4: 178. doi: 10.4172/2155-9554.1000178.

2. Dr.Ganesh Garde, editior. SarthVagbhata. Sharirasthan. Chapter 3. Varanasi: Chowkhambha Surbharati publication; 2009. p.142.

3. Kashyap

4. Dr. Ganesh Garde, editior SarthVagbhata, Sutrasthan Chapter 11, Varanasi Chowkhambha Surbharati publication; 2009. p.34

5. Dr. BrahmanandTripathi and Dr. Ganga SahayPandey, editors. Charak Samhita of Agnivesha, Sutrasthan. Chapter 28. Delhi: Chaukhamba Sanskrit Pratisthan; 2006. p.548

6. Dr. BrahmanandTripathi and Dr. Ganga SahayPandey, editors. Charak Samhita of Agnivesha, Chikitsasthan. Chapter 15. Delhi: Chaukhamba Sanskrit Pratisthan; 2006. p.326

7. Sharangdhar samhita

8. Dr.Ghanekar, commentator. Sushruta Samhita, Sutrasthan. Chapter 15. New Delhi: MaeherchandLachmandas Publication; 2013. p.140
9. Dr.BrahmanandTripathi and Dr. Ganga SahayPandey, editors. Charak Samhita of Agnivesha, Sutrasthan. Chapter 17. Delhi: Chaukhamba Sanskrit Pratisthan; 2006. p.351

10. Dr.Ghanekar, commentator. Sushruta Samhita, Uttartantra. Chapter 8. New Delhi: Maeherchand Lachmandas Publication; 2013. p. 210

11. Dr.BrahmanandTripathi and Dr. Ganga SahayPandey, editors. Charak Samhita of Agnivesha, Vimansthan. Chapter 5. Delhi: Chaukhamba Sanskrit Pratisthan; 2006. p.698

12. Dr.Ganesh Garde, editior. SarthVagbhata. Sutrasthan. Chapter 2. Varanasi: Chowkhambha Surbharati publication; 2009. p.7,8,9

13. Dr.BrahmanandTripathi and Dr. Ganga SahayPandey, editors. Charak Samhita of Agnivesha, Sutrasthan. Chapter 5. Delhi: Chaukhamba Sanskrit Pratisthan; 2006. p.122-135

14. Dr.BrahmanandTripathi and Dr. Ganga SahayPandey, editors. Charak Samhita of Agnivesha, Sutrasthan. Chapter 6. Delhi: Chaukhamba Sanskrit Pratisthan; 2006. p.151-158

15. Dr.Ganesh Garde, editior. SarthVagbhata, Sutrasthan. Chapter 11, Varanasi: Chowkhambha Surbharati publication; 2009. p.53

16. Dr.BrahmanandTripathi and Dr. Ganga SahayPandey, editors. Charak Samhita of Agnivesha, Vimansthan. Chapter 1. Delhi: 
Chaukhamba Sanskrit Pratisthan; 2006. p.661

17. Dr.BrahmanandTripathi and Dr. Ganga SahayPandey, editors. Charak Samhita of Agnivesha, Sutrasthan. Chapter 8. Delhi: Chaukhamba Sanskrit Pratisthan; 2006. p.199

18. Dr.BrahmanandTripathi and Dr. Ganga SahayPandey, editors. Charak Samhita of Agnivesha, Sutrasthan. Chapter 5. Delhi: Chaukhamba Sanskrit Pratisthan; 2006. p.133

19. Dr.BrahmanandTripathi and Dr. Ganga SahayPandey, editors. Charak Samhita of Agnivesha, Sutrasthan. Chapter 5. Delhi: Chaukhamba Sanskrit Pratisthan; 2006. p. 127

20. Dr.Ganesh SarthVagbhata. Chapter Garde, editior. 39
Chowkhambha Surbharati publication; 2009. p.476

21. Dr.Ganesh Garde, editior. SarthVagbhata. Uttartantra. Chapter $39 . \quad$ Varanasi: Chowkhambha Surbharati publication; 2009. p.486

22. Dr.Ganesh Garde, editior. SarthVagbhata. Uttartantra. Chapter $39 . \quad$ Varanasi: Chowkhambha Surbharati publication; 2009. p.485

23. Dr.BrahmanandTripathi and Dr. Ganga SahayPandey, editors. Charak Samhita of Agnivesha, Chikitsasthan. Chapter 25. Delhi: Chaukhamba Sanskrit Pratisthan; 2006. p.324

24. Dr. Ghanekar, commentator. Sushruta Samhita, Chikitsasthan. Chapter 1. New Delhi: MaeherchandLachmandas Publication; 2013. p.221 25. Sharangdhr samhita, uttarkhand 11 